\title{
Monitoring Migratory BIRd PopUlations IN Grand Teton National Park, NORTHERN ROCKY MOUNTAINS
}

\author{
MARTIN L. CODY $\bullet$ DEPARTMENT OF BIOLOGY \\ UNIVERSITY OF CALIFORNIA $\bullet$ LOS ANGELES \\ STEVEN CAIN $\bullet$ RESOURCE MANAGER, NPS \\ GRAND TETON NATIONAL PARK $\bullet$ MOOSE
}

\section{- INTRODUCTION}

A scheme for long-term monitoring of breeding land bird populations in a wide variety of habitats representative of the northern Rockies and the Greater Yellowstone Ecosystem (GYE) was initiated in summer 1993. It is projected that the monitoring scheme, when fully established and formalized, will become a routine activity in Grand Teton National Park, where a broad range of representative vegetation types is accessible within close geographic proximity. Sixteen study sites were established within the park in pristine habitat, from the Jackson Hole lowlands to subalpine and alpine sites, from meadow, sagebrush and marshland, through willow scrub, cottonwood and aspen woodlands, to lodgepole pine and spruce-fir forests. Some of the study sites have a long history of research on the breeding birds (see below). Census sites are standardized at $\mathbf{5}$ ha in size, and mapped in detail (topography, vegetation).

The locations and accessibility of the study sites permit all to be regularly and repeatedly censused during the short (6-week) breeding season. Census schedules, timing, and methodological protocols are being established and refined, to provide for strictly controlled inter-site and inter-year comparisons in breeding bird populations, species composition, and densities. In view of the projected benefits to science and resource management of this monitoring scheme, the project hopefully will be continued and the data base further expanded in future years, with a larger range of study sites (2436).

\section{THE ROLE OF LONG-TERM STUDIES}

Long-term studies on breeding bird species and densities are an important tool for evaluating the impact of both local and distant influences on breeding bird populations. Local effects include nonbreeding season influences on species that are resident or short-distance (e.g. elevational) migrants, as well as influences on breeding population densities via inter-year changes in on-site vegetation structure and productivity. Distant influences refer to factors affecting over-wintering success, and therefore prebreeding densities, of species that are either longdistance (neotropical) or medium-distance migrants (largely to areas in the southern and southwestern US).

There is much concern at present over declining breeding densities of migratory songbirds, particularly in the eastern U.S. (e.g. Keast \& Morton 1974, Terborgh 1989, Smithsonian Institution 1991), with the likely causal factors associated with both clearing and increased fragmentation of breeding habitats, and reduced availability of wintering habitat. To date, most of this concern has been focussed on 
the breeding migrants of the NE forests, and their wintering habitats on Caribbean islands, on the Caribbean slope of Central America, and in northern South America. However, many paruline warblers of the northern Rockies winter in western Mexico, where they are common in lowland edge habitats and comprise $25-50 \%$ of local winter bird densities (Hutto 1980, Cody 1983, Terborgh 1989); these wintering habitats also are vanishing at alarming rates (Hutto 1986).

In response to this concern, the National Fish and Wildlife Foundation has initiated the Neotropical Migratory Bird Conservation Program (National Fish and Wildlife Foundation 1992), which involves cooperative partnerships among federal, state, and local government agencies, academic institutions, and conservation organizations in North and Latin America. The first comprehensive nongame bird conservation program initiated since the passage of the Migratory Bird Treaty Act of 1918, its goal is to improve monitoring, research, management, and education programs involving neotropical migratory birds and their habitats. Primary monitoring goals include 1) obtaining reliable information on the population status of neotropical migratory birds to allow assessment of population trends, and 2) expanding surveys in North America to include inadequately covered species and regions (National Fish and Wildlife Foundation 1992).

An additional indication of the extent and depth of concern for populations of neotropical migrant birds that breed in the US is gained from the focus of the Ecological Society's 1993 annual meeting (Madison, WI; Ecological Society of america 1993). Sections were dedicated to long-term studies (including one co-organized by MLC in which studies on bird populations in GTNP were discussed), population viability and ecological risk management, and the management of ecosystems on lands under federal jurisdiction. Besides these foci, one symposium specifically addressed local and regional trends in neotropical migrants, and at least a dozen additional papers on the topic were presented.

Besides a reduced availability of wintering habitat for long-distance migrants, more local effects can influence breeding bird densities. Populations can vary year-to-year in response to the vagaries of over wintering success, even in short-distance migrants and residents. Further, breeding habitats may change over the longer term in areal extent or degree of fragmentation, and may vary among years in qualities that affect their carrying capacities for breeding birds. Environmental variations, both abiotic and biotic, can affect survival at any stage in the life-cycle, producing variations in breeding density and associated factors (habitat preference, community structure and organization). Whether or not the consequences of such extrinsic and intrinsic variability alter or obscure patterns in the breeding community itself varies; in some cases, density changes produce readily interpretable alterations in bird communities (e.g. via density compensation, or shifts in habitat occupancy), while in others such interpretations are apparently not possible (see, e.g. Wiens 1984, 1988 references therein).

Some intrinsic variation (e.g. changes in carrying capacity) in breeding bird density is usual and has a clear explanation. Overwinter precipitation affects insect productivity in more xeric habitats, and larger territory sizes, correlated with lower resource availability, may reduce densities in drier years (Cody 1981). In some wetland habitats, standing water may buffer the spring productivity against drier winters, but vegetation structure and resource productivity are clearly affected by other factors such as the presence of large browsers (especially moose), and likely by changes in water levels (through runoff, beaver activity, etc.).

In areas like Jackson Hole, with a steady and heavy human visitation rate, it seems important to measure the long-term trends in bird densities as a form of bioassay of the state of the local environments. Information from such studies can provide region-wide indicators, and can be incorporated into management strategies to aid in determining which steps may be necessary (and feasible) to help maintain the biota.

The project initiated in 1993 has a single primary objective, to evaluate local, regional, and to some extent continental, populational trends of birds that breed in the northern Rocky Mountains in general, and in the Greater Yellowstone Ecosystem (GYE) in particular. Secondary objectives aim to identify and distinguish between factors in year-toyear population variations that are intrinsically-driven (i.e., within-park) and those that are extrinsic (i.e. controlled by influences outside the GYE), and to 
examine the relationships among habitat availability, habitat utilization and productivity, and species composition and densities in the study habitats.

\section{STUDY SITES: CLIMATE, PHYSIOGRAPHY, AND VEGETATION}

Grand Teton National Park (GTNP) is an ideal locale for monitoring breeding bird populations, since it combines relatively small area (ca. $1500 \mathrm{~km}^{2}$ ) with easy accessibility and complete range of habitats representative of the GYE. Elevations in the park encompass the range from the Snake River bottomlands at $1900 \mathrm{~m}$ to some of the higher peaks in the region $(4173 \mathrm{~m})$, together with the arctic-alpine habitats in their vicinity. The topographical relief in the park is unmatched in other areas of comparable size, and this confers a range of habitats that is unparalleled in other regions of comparable extent in the northern Rockies. The evolution of this unique landscape is well described in Love and Reed (1968), and a forthcoming treatment by Knight (1994) places the region in a geological as well as ecosystem perspective. The climate in GTNP is representative of the elevation and location; there is moderate seasonality and year-to-year variation in precipitation, but strong seasonality and high year-to-year variation in monthly mean temperatures. With an average 35 frost-free days/year on the floor of Jackson Hole (Cody 1974), bird breeding seasons are necessarily short in this area.

The broad range of habitats in GTNP reflect the area's striking topography and wide range of elevation and climatic conditions. The Snake River bottomlands are patchily forested, with blue spruce Picea pungens, cottonwoods Populus angustifolia and $P$. trichocarpa, and lodgepole pine Pinus contorta. Interspersed among the forest patches are many marshy oxbows, ponds and associated willow Salix spp. flats. Drier forb- meadowland and wetter sedgegrassland also occur throughout the lower elevations. The upper riverside benches and floor of Jackson Hole are largely sagebrush Artemisia tridentata and A. cana/grassland Festuca spp. and Poa spp. flats, with a substantial bitterbrush component Purshia tridentata in some areas. Lower hillsides and morainal slopes around the Hole are largely wooded with lodgepole pine Pinus contorta, with some areas also supporting Douglas fir Pseudotsuga menziesii. Denser forests of Engelmann spruce Picea engelmannii and subalpine fir Abies lasiocarpa become predominant somewhat higher and especially in the foothills at the eastern base of the Teton range. Closed and open stands of whitebark pine Pinus albicaulus occur above $2400 \mathrm{~m}$ elevation. Aspen Populus tremuloides form extensive stands on the foothills of the Gros Ventre Mountains that border the valley to the east, and occur elsewhere in landslide or other disturbed areas. Above timberline (ca. $3500 \mathrm{~m}$ ) the arctic-alpine zone is vegetated largely by perennial, rosette-forming forbs. Foliage profiles of several representative habitats are shown in Fig. 1, and an analysis (FA) based on the vegetation structure of the major habitats is given in Fig. 2.

\section{BREEDING BIRD POPULATIONS AND MIGRATION BEHAVIOR}

GTNP is relatively rich in bird species, encompassing as it does a wide range of habitats from near-desert to abundant wetlands, from lowland to montane habitats, and from grasslands to tall forests. An indication of this diversity is gained from Table 1 (see below), which lists 76 breeding landbird species found on just 165 ha sites; this number represents about two-thirds of the landbird species that are known to breed in GTNP on a regular basis.

The avifauna of GTNP is ideal for testing theories about population trends in bird populations, because there are many species representative of each of the migration strategies: long-distance migrants (neotropical, mainly W Mexico), mid-distance migrants (mainly SW USA and NW Mexico, wintering in desert and desert-grassland habitats), short-distance (elevational and local) migrants, and year-round residents. Further, the geographical position of GTNP, in the Northern Rockies and at the western edge of the Great Plains, provides substantial numbers of breeding birds that are either chiefly eastern in distribution, and reach their western limits in or near GTNP, or species that are largely western in distribution, and extend no or scarcely farther east than GTNP. Besides these, of course, there are species in all categories of migration strategy that extend much further east and west of the northern Rockies. This variety will enable the influence of breeding site relative to centers of geographic distribution to be evaluated in terms of population trends and migratory status. 
Table 1. Jackson Hole birds.

\begin{tabular}{|c|c|c|c|c|c|c|c|c|c|c|c|c|c|c|c|c|c|c|}
\hline HABTTAT & Grm & Girs & ins & $\mathrm{FbMM}$ & Down & Tw/WII & WIAsp & LAsp & M/Asp & TIAsp & Scott & Sarcot & AMIKa & Siglp & West & Jensf & 1837 Status & 1891 \\
\hline Specles/She & 2 & 3 & 4 & 5 & \begin{tabular}{|l|}
3 \\
\end{tabular} & 8 & 9 & 10 & 11 & 12 & 13 & 14 & 18 & 10 & 20 & 21 & & status \\
\hline Bam swallow & + & & & & & & & & & & & & & & & & FOOM & Com \\
\hline Marsh hawk & + & & & & & & & & & & & & & & & & UNC & $\infty$ \\
\hline Cliff swallow & + & + & & & & & & & & & & & & & & & roOM & ABUN \\
\hline Brewer blackblind & + & + & + & + & + & & & & & & & & & & & & UNC & $\infty$ \\
\hline Sanchlll crane & + & $t$ & & + & & & & & & & & & & & & & NL (Rare, V & $\infty$ \\
\hline Savannah sparrow & + & + & & + & + & + & & & & & & & & & & & FCOM & $\infty$ \\
\hline Raven & + & + & + & + & + & & + & + & + & + & + & + & + & + & + & + & room & $\infty$ \\
\hline Swalnson's hawk & + & & & + & & & & & + & & & & & & & $E$ & FOOM & $\infty$ \\
\hline Snipe & + & & & + & + & + & & & & & E & & & & & & NL $(O \infty, y$ & $\infty$ \\
\hline Vesper Spanow & & + & + & + & & & & & & & & & & & & & ABUN & $\infty$ \\
\hline Brewer's epanrow & & + & + & + & & & & & & & & & & & & & $\infty$ & $\infty$ \\
\hline Whitte-cr.sparrow & & It & & + & + & + & + & $1+$ & + & & + & + & + & & + & & UNC & ABUN \\
\hline Starling & & + & & + & 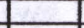 & & 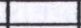 & & & & & 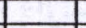 & & & 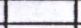 & & NOT LSTED & $\infty$ \\
\hline Br.head conbird & & + & & + & $t$ & + & + & & + & & & + & + & & + & & NL (Com., n & $\infty$ \\
\hline Robin & & + & & + & + & + & + & + & + & + & + & + & + & + & + & + & ABUN & ABUN \\
\hline Red-sh.flicker & & + & + & + & + & + & + & + & + & + & + & + & + & + & + & + & ABUN & $\infty$ \\
\hline W.Meadowlark & & & + & 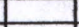 & & & & & & & & & & & & & UNC & $\infty$ \\
\hline Sage thrasher & & & + & & & & & & & & & & & & & & PARE & $\infty$ \\
\hline Sage grouse & & & + & & & & & & & & & & & & & & $\infty$ & $\infty$ \\
\hline Green-L.towhee & & & + & & + & & & + & + & + & + & & & + & & & RAFE & $\infty$ \\
\hline Song sparrow & & & & + & + & + & + & & & & & + & & & & & Dom & Com \\
\hline Amer.poldfinch & & & & + & & & & & + & & & & & & & & $\infty$ & $\infty$ \\
\hline Red-wing blackdd & & & & + & & & & & & & & & & & & & $\infty$ & $\infty$ \\
\hline Tree swallow & & & & + & + & & + & + & + & + & + & + & + & & & & $A B C N$ & ABCW \\
\hline Br.tall.hummingt & & & & + & & & + & & + & + & & & & & & & $\infty$ & $\infty$ \\
\hline Willow flycatcher & & & & + & + & + & + & & & & & & & & & & UNC & $\infty$ \\
\hline House finch & & & & + & + & & & + & + & & & + & & & & & & \\
\hline Uncoln's sparrow & & & & + & + & + & + & & & f & + & & & & + & & UNC & $\infty$ \\
\hline Violet-gr.swallow & & & & & + & -1 & & & & 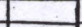 & & & + & 1 & & & FoOM & $\infty$ \\
\hline Am. crow & & & & & + & + & & & & & & & & & & & NL (Comm, $n$ & $\infty$ \\
\hline Yellowthroat & & & & & + & + & & & & & & & & & & & UNC & $\infty \mathrm{cm}$ \\
\hline Yellow warbler & & & & & + & + & + & + & + & + & + & + & & & & & ABCN & ABUN \\
\hline Fox sparrow & & & & & + & + & + & & & & + & & & L & & & FCOM & $\infty$ \\
\hline Kestrel & & & & & + & & & & + & + & & & & & & & $\infty$ & $\infty$ \\
\hline Magpie & & & & & + & + & + & & & 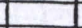 & T & F & & & & & JuNC & $\infty$ \\
\hline Blk-c.chickadee & & & & & + & + & + & + & + & + & + & + & & & & & $\infty$ & $\infty$ \\
\hline Wilson's warbler & & & & & + & + & + & & & & & & & & & & NL (Com., $Y)$ & $\infty$ \\
\hline Warbling vireo & & & & & + & + & + & + & + & + & + & + & + & + & + & + & $\infty$ & ABUN \\
\hline Colliope humming & & & & & & + & & & & & + & & & & & & RuNC & $\infty$ \\
\hline Marsh wren & & & & & & + & & & & & 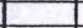 & 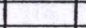 & 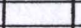 & 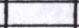 & & 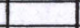 & NL (Rep, $\eta$ & $\infty$ \\
\hline N. Waterthrush & & & & & & + & & & & & & & & & & & NOT USTED & PAFE \\
\hline MacGillivray's w. & & & & & & & + & & + & & & & & & & + & UNC & $\infty$ \\
\hline Least flycatcher & & & & & & & & + & + & + & + & + & & & & 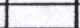 & $?$ & $\infty$ \\
\hline House wren & & & & & & & + & + & + & + & + & + & & & & 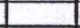 & FOOM & क्M \\
\hline Downy woodpeckr & & & & & & & + & + & + & + & + & + & & & & & FOOM & $\infty$ \\
\hline Dusky flycatcher & & & & & & & + & + & + & + & + & + & & & & + & NL (Comm, Y) & com \\
\hline Swainson's thrush & & & & & & & + & & & & & & + & + & + & + & NL (Res., $y$ & com \\
\hline Bi-headed grosblk & & & & & & & + & & & & & + & & & & + & FCOM & COM \\
\hline Red-n.sapsucker & & & & & & & + & & + & + & + & + & + & & & t & ABUN & $\infty$ \\
\hline Orang.-cr.warbler & & & & & & & & + & + & & & & & & & & & \\
\hline W.wood pewee & & & & & & & & + & + & + & + & + & + & & & + & ABCN & $\infty$ \\
\hline Mt. bluebind & & & & & & & & + & + & + & + & + & & & & & ABUN & $\infty$ \\
\hline Yellow-r.warbler & & & & & & & & + & + & + & + & + & + & + & + & + & ABUN & ABUN \\
\hline Dark-eyed Junco & & & & & & & & + & + & + & + & + & + & + & + & + & $\infty$ & $A B C N$ \\
\hline Red-tailed hawk & & & & & & & & + & + & & + & + & & & & & $\infty$ & $\infty$ \\
\hline Wh.br.nuthatch & & & & & & & & + & + & & + & & & & 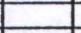 & & NL (Unc., $Y)$ & $\infty$ \\
\hline Pine siskin & & & & & & & & & + & + & . & + & + & + & + & + & $\infty$ & $\infty$ \\
\hline Ruffed grouse & & & & & & & & & + & & & + & & & + & & FCOM & DM \\
\hline Chipping sparrow & & & & & & & & & & + & & + & + & + & + & + & ABUN & $\infty$ \\
\hline Red crossbill & & & & & & & & & & + & & & + & + & + & & NL (Com., n & $\infty$ \\
\hline Ruby-cr.kinglet & & & & & & & & & & & + & + & + & + & + & + & ABUN & Dom \\
\hline Cassin's finch & & & & & & & & & & & + & & + & & + & + & $\infty$ & $\infty$ \\
\hline Pine grosbeak & & & & & & & & & & & + & & + & & + & & FARE & $\infty$ \\
\hline Red-br.nuthatch & & & & & & & & & & & & + & + & + & + & + & $A B C W$ & $\infty$ \\
\hline Cedar waxwing & & & & & & & & & & & & + & & & & & FARE & $\infty$ \\
\hline Mt. chickadee & & & & & & & & & & & & + & + & + & + & + & $\infty$ & $\infty$ \\
\hline Gray lay & & & & & & & & & & & & & + & + & & . & UNC & $\infty$ \\
\hline Clark's nutcracker & & & & & & & & & & & & & + & & + & + & $\infty$ & $\infty$ \\
\hline Western tanager & & & & & & & & & & & & & + & + & + & + & $\infty$ & $\infty$ \\
\hline Ol.sided flycatcher & & & & & & & & & & & & & + & + & + & + & POOM & $\infty$ \\
\hline Hairy woodpecker & & & & & & & & & & & & & + & + & + & + & VOM & $\infty$ \\
\hline Blue grouse & & & & & & & & & & & & & +1 & & & & $\infty$ & $\infty$ \\
\hline Brown creeper & & & & & & & & & & & & & + & + & + & + & PAFE & $\infty$ \\
\hline Hermit thrush & & & & & & & & & & & & & + & + & + & + & $\infty$ & $\infty$ \\
\hline C. nighthawk & & & & & & & & & & & & & & + & & & & \\
\hline N.3-td.woodpkr & & & & & & & & & & & & & & & & + & NL (Rare, $\eta$ & $\infty$ \\
\hline
\end{tabular}




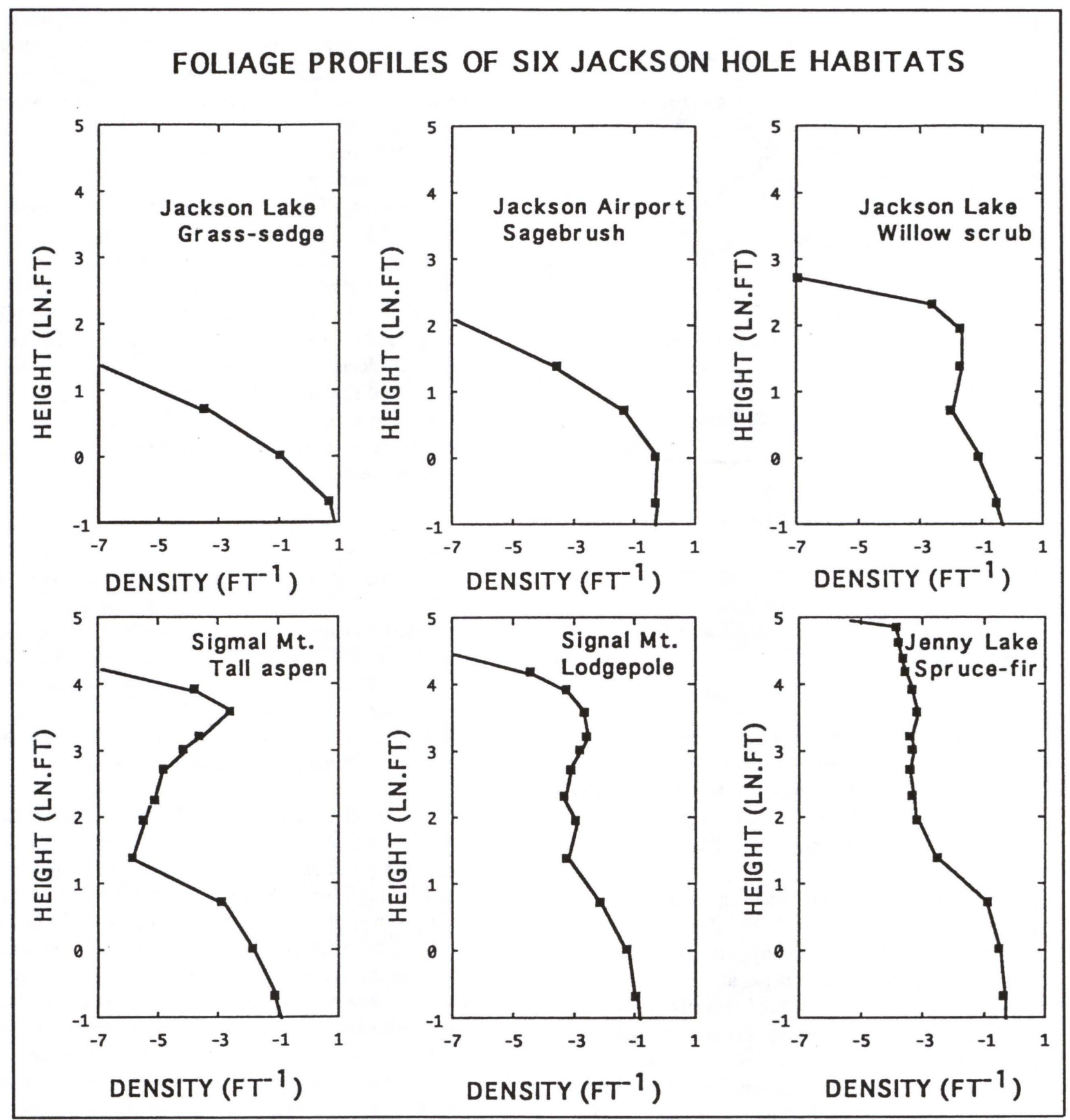

Figure 1. Vegetation profiles of some representative habitats in Grand Teton National Park.

\section{EARLIER WORK IN GTNP}

A considerable amount of earlier work constitutes a firm basis for an extended and extensive monitoring scheme. Between the establishment of the park (1929) and its present-day configuration (1950), bird status surveys were conducted 1933-37 (USDI,
Washington). Salt (1957) reported on habitat selection and relative abundances of Lincoln's, Fox and Song Sparrows, and subsequently his site (Wet Willows site \#8) was studied intensively by MLC in the late 1960's and into the 1970's (Cody 1974), and again in 1991-1993 (Cody 1991, 1992, 1993). A second site we propose to use (Grass-sage site \#3) 


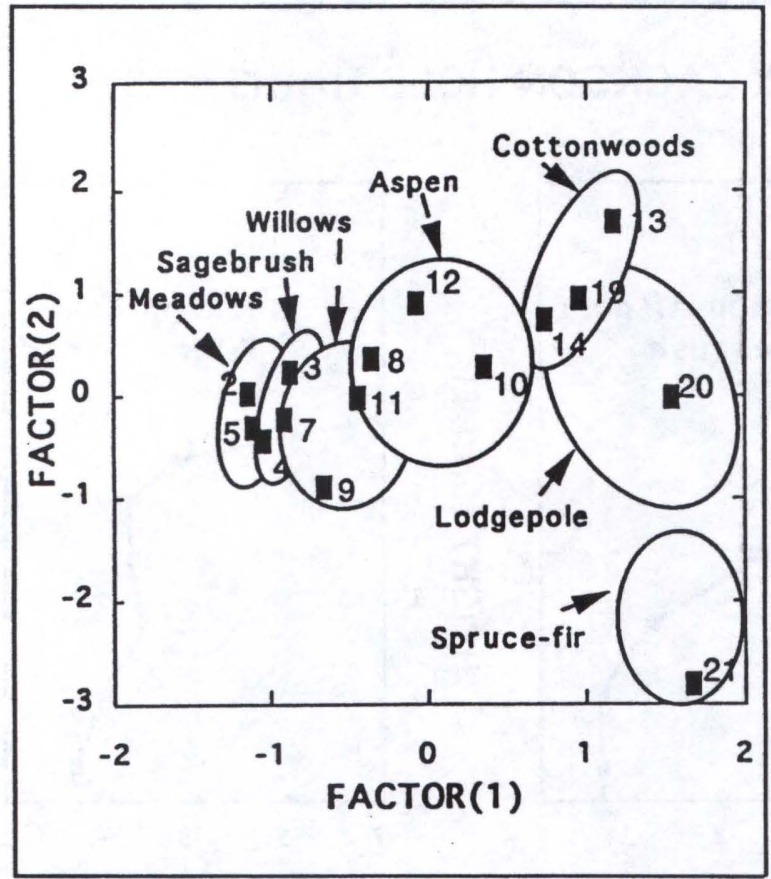

Figure 2. Factor analysis of vegetation characteristics of some census sites in Grand Teton National Park.

has likewise been studied by MLC since the 1960's, and the three aspen census sites (\#s 10, 11, 12) were first censused by D. Flack in the 1960's (Flack 1976). Thus for several sites there exist bird population data extending back $>25$ years.

In addition to these sources, there are informal records collected by the Grand Teton Natural History Association by way of the check-list program, and staff and students at the Teton Science School may also have bird census data of a quantitative nature that would enhance the data base for the area. All such sources can be assessed to provide background information, and integrated into the broad picture of bird population trends in GTNP.

The earlier surveys from the 1930's provide useful qualitative data for comparison with presentday estimates of bird occurrences and densities, and give a perspective of over half a century on changes in the GTNP avifauna. Of the species that were listed in the 1930's survey and do not occur in the sixteen sites recorded in Table 1 , several would be expected, but have apparently declined in abundance over the last half century (Table 2). Of these species, Clay-colored sparrow, was relatively common in several GTNP sites in the late 1960's (MLC; site \#8, and in scrubby habitats up the Gros Ventre valley), but it appears to have disappeared from the park in the 1990's. Notably, several additional species typical of grasslands, open or brushy country have apparently declined (Eastern* and Western Kingbirds, Bobolink*, Lark sparrow, Gray catbird*, Clay-colored sparrow*, Lark bunting*, Vesper sparrow, Western Meadowlark) in the recent decades. Those marked '*' are near the western limits of their breeding ranges in GTNP. Conspicuous among others that appear to have suffered declines are several orioles, warblers, vireos, and finches with neotropical or far southerly wintering ranges; about one-half of the species that seem to have maintained constant densities are yearround residents.

On the other hand, about $1 / 2$ the species listed in Table 1 appear to be more common now than in the 1930's, two of these conspicuously so (Table 2). These and several others appear to have increased moderately to dramatically in abundance (including Cliff swallow, Sandhill crane, Starling, Green-tailed towhee, Lincoln's sparrow, Yellowthroat, Magpie, Wilson's warbler, MacGillivray's warbler, Dusky Flycatcher, Swainson's thrush, White-breasted nuthatch).

Work to date at two GTNP sites reveals that censuses can show considerable inter-year variation in breeding bird densities. For example, comparisons of 1966 densities with those of 1991-1993 show that changes in bird density are overall just as likely and as great between adjacent census years as between censuses 25 years apart (Cody 1992), and no more dramatic among the longer-distance migrants than among residents and short-distance migrants. Tables 3-4 give an indication of such inter-year variation. In the Grass-sage site (\#3), total breeding bird density has remained \pm constant over 25 years, although one new species has shown up recently (Chipping sparrow), Savannah and Brewer's sparrow densities were high in 1992, and the latter was less common in 1993 when White-crowned sparrow and Vesper sparrows were more common. In the Willows site (\#8), again total breeding bird density is not very different over 25 years, but species favoring drier sites have declined, and those favoring wetter sites have increased since 1966: the latter category includes Song and Savannah sparrows, Marsh wren 


\begin{tabular}{|c|c|c|c|}
\hline Species & 1930 's status & 1960 's & 1990 's \\
\hline \multicolumn{4}{|c|}{ Species that have apparently declined since the 1930 's: } \\
\hline Stellar's jay & common & 1 restr.. S end of part & 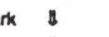 \\
\hline Common grackle & common & 'S of Jackson Hole & 1 \\
\hline Golden-cr. kinglet & occasional & NS2 & $\$$ \\
\hline Veery & occasional & NS2 & t \\
\hline American redstart & occasional & NS2 & $\$$ \\
\hline Lark sparrow & occasional & 'poss. migration onit & $\$$ \\
\hline Bobolink & occasional & $1_{\text {poss. Nat. Elk Rof. }}$ & t \\
\hline Northern oriole & occasional & 1restr.. South Park & $\$$ \\
\hline Evening grosbeak & occasional & 1 winter only & $\$$ \\
\hline Winter wren & rare & Tone recent record & 8 \\
\hline Loggerhead shrike & rare & NS2 $^{2}$ & 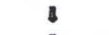 \\
\hline Solitary vireo & rare & NS2 & 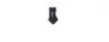 \\
\hline Tennessee warbler & rare & NS2 & $\$$ \\
\hline Townsend's warbler & rare & NS2 & 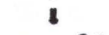 \\
\hline Clay-colored sparrow & rare & common $2 \pi$ & absent 2 \\
\hline Lark bunting & rare & NS2 $^{2}$ & 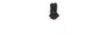 \\
\hline \multicolumn{4}{|c|}{ Species that have apparently increased since the 1930 's: } \\
\hline $\begin{array}{l}\text { Bi.-headed cowbird } \\
\text { White-cr, sparrow }\end{array}$ & $\begin{array}{l}\text { unlisted } \\
\text { uncommon }\end{array}$ & $\begin{array}{l}\text { occasional in } \\
\text { abundant it }\end{array}$ & $\begin{array}{l}\text { ammon it in } \\
\text { bundant it it }\end{array}$ \\
\hline
\end{tabular}

and Northern waterthrush, and in the former are Swainson's thrush, and Lincoln's, White-crowned and Clay-colored sparrows. Apart from these siterelated changes and density shifts, several species show variable interyear density without any apparent local explanation; for example, Wilson's warbler was extremely rare in 1992 (as it was also park-wide), but it and MacGillivray's warblers were both common in 1993. Orange-crowned warbler was also notably commoner in 1993 (in GTNP aspens) than ever before recorded by the author.

Through previous work in GTNP, we have a grasp of what long-term changes have occurred, and have gained a considerable understanding of species' distributions within the park, of species' habitat preferences, and of the sorts of inter-year variations in population densities that might be typical. This existing information will greatly facilitate the instigation of an appropriate monitoring program for GTNP habitats.
Table 3. Site characteristics and bird community in grass-sagebrush GS site. For each species. "quads occupied" indicates " of $15 \mathrm{~m} \times 15 \mathrm{~m}$ quadrats

within the species' territories. and "breeding pairs" indicates the total number of pairs with territories complotoly within or partially overlapping

the study site. Total breeding density has units of prs/ha.

\begin{tabular}{lllll}
\hline Study Yoar: & 1966 & 1991 & 1992 & 1993 \\
\hline
\end{tabular}

Sito area: $\quad 4.97 \mathrm{ha} \quad 4.97 \mathrm{ha} \quad 4.68 \mathrm{ha} \quad 4.68 \mathrm{ha}$

Brewers sparrow $\begin{array}{lcccc}\text { Ouads oceupied } & 108 & 58 & 101 & 31 \\ \text { Breeding pairs } & 6 & 5 & 9 & 5\end{array}$ $\begin{array}{llcll}\text { Breeding pairs } & 6 & 5 & 9 & 5 \\ \text { Tol. breeding density: } & 0.92 & 0.82 & 1.15 & 0.35\end{array}$

Chipoing sparrom $\begin{array}{lllll}\text { Quads occupied } & 0 & 12 & 0 & 26\end{array}$

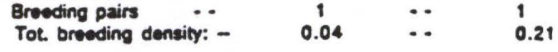

Whito-erowned sparrow $\begin{array}{lllll}\text { Ouads cocupied } & 45 & 18 & 31 & 35\end{array}$ $\begin{array}{lccll}\text { Breecting pairs } & 2 & 2 & 2 & 2 \\ \text { Tol breeding density: } & 0.28 & 0.26 & 0.28 & 0.32\end{array}$

Vesper sparrow $\begin{array}{lllll}\text { Quads occupied } & 129 & 55 & 83 & 118\end{array}$

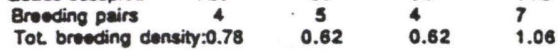

Savannah sparrow $\begin{array}{lllll}\text { Quads occupied } & 67 & 40 & 74 & 57\end{array}$

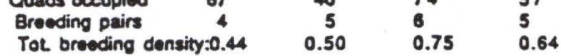
SUMMARY:

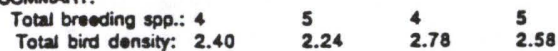

Species also commonly present:

Cliff swallow Retrecheliden exrrhoneta

Brower's blackbird Euphagus gyanoceohalus

Brown-headed cowbird Molothrus ater

Staring sturaus t+ +

Starting Sturnus vuloaris

\section{- METHODOLOGY FOR POPULATION MONITORING}

\section{CENSUS SITES}

Sixteen of an eventual 24-30 census sites have been established for the purpose of monitoring bird populations. The full range of sites will span elevations from $1950 \mathrm{~m}$ to $>3400 \mathrm{~m}$, encompassing the complete range of the park's major habitat types, and will be distributed more or less equitably throughout the park as is shown in Fig. 3. The 16 study sites already selected were used in 1992 and 1993 to generate the data of Table 1 and the representations of vegetation in Figs. 1 and 2. These sites include five that have been censused for 
extended periods of time, back into the 1950's and 1960 's, and which we anticipate will be especially valuable: site \#3 (grass-sage), \#8 (wet willows), and D. Flack's three aspen census sites (\#s 10, 11, 12). These and other proposed census sites (a further nine tentatively located and visited) span the range of available habitats, and are listed in Appendix A.

\section{CENSUS SCHEDULE AND TIMING}

The number of monitoring sites that can be routinely censused depends on the personnel available (and capable) of performing the census work and rotation. Ideally, each census site would be censused three times, at one-week intervals, during the height of the breeding season. The ideal timing for the census rotation normally extends from the last week of June through the middle of July, but could be extended a week or so in both directions. This prime breeding season does not vary much in extent among years, but varies \pm 2 week from year to year depending on the earliness or lateness of the season in a specific year. An example of a three week rotation involving 18 census sites is shown in Appendix B; a single qualified person, working fulltime, could accomplish this work, but additional sites would require additional personnel in the field, optimally two full-time monitors for the length of the breeding season.

\section{CENSUS METHODOLOGY}

Three main methodologies are in vogue for bird census work: a) territory mapping, b) transect counts, and c) point census techniques. These methods have been recently described in detail, compared and reviewed by Bibby et al. (1992). Each technique has its advantages and disadvantages: a) is most accurate, but is very time-consuming, $b$ ) is most useful for rough surveys of large areas of homogeneous habitat, and c) gives a good relative count for very small areas, but is strongly affected by the differing detectability of bird species. Both b) and c) need standardizing by species' detectability and observer acuity in complex ways before bird densities, in terms of breeding pairs/area, can be derived (Bibby et al. 1992).

We have used a method that is a combination of all three techniques, referred to as an "areal count", similar to the "spot-mapping" technique first described by Kendeigh (1944). It maximizes 
accuracy and the facility with which different observers can duplicate each other's results and observations, while minimizing the work required to plot actual territories and the difficulties with transcribing transect or point census data to real breeding densities. Census areas are sited accurately on the standard GTNP topographical map, and specific boundary points permanently marked. Each census site is standardized at $\pm 5 \mathrm{ha}$, and mapped for topographical features and anomalies; a site map is then prepared, such that an observer can always identify his/her position within the site, and locate permanent markers within the site.

Within the sites, a \pm fixed path is taken (as in transect counts) between specific observation points (marked, as in point censuses) that are located each 100-200 $\mathrm{m}$ for convenient observation. Bird species and individuals are located during the transect walk around the site, and during 10 minute pauses at the specific observation points (usually 4-6) along the transect. Two hours is allocated for each census, about half of which is spent at the observation points, and half walking between them through the site. Each identified sight and sound record is marked on the site map; a fresh map is used for each census at each site. While actual territory boundaries are not plotted, the locations of foraging, nesting and/or singing birds are all recorded on the site map. Densities are then derived from accumulated mapped observations, by drawing up a species map for each species found at the site, using the same site map master. By delineating areas consistently used by individual pairs and distinguishing them from areas used by other conspecific pairs, the density of each species can be determined (Bibby et al. 1992, Ch. 3). Mapping the locations of individuals, even approximately, minimizes difficulties stemming from duplicated records (multi-listing). since all parts of the site are covered slowly and carefully, rarer and/or more secretive species are unlikely to be overlooked, and are scored proportionately with common species.

Censuses are made at three times of day, early morning (6-8 am), late morning (8-10 am), and late afternoon (3-5 pm), avoiding the midday and early afternoon periods of reduced foraging and territorial activity. For efficiency and logistic reasons, censuses will be grouped such that nearly adjacent sites are censused within the same morning.

\section{HABITAT SAMPLING}

Habitat sampling includes quantitative measurements of at least eight physical, structural and floristic parameters at a minimum of three points in each census site, following procedures described by James and Shugart (1970) and Noon (1980). Sampling is conducted within 0.04 ha circular plots at each site. Vegetation profiles will be derived from site averages of these measurements, and additional habitat sampling, such as that described by Ralph et al. (1992), relevant to the Neotropical Migratory Bird Program, could be conducted at some future point in time if and when recommendations and standards are developed.

In addition, a complete monitoring scheme would wish to consider sampling insect abundances, perhaps by means of Tanglefoot ${ }^{\circ}$ traps, as an index of inter-year variation in site productivity, but details of an appropriate sampling program must await manpower assessments.

\section{STATISTICAL ANALYSES}

The first-stage product of the monitoring program is a series of estimates of breeding bird densities. These are species-, site-, and year-specific, forming a 3-D matrix of density estimates. Along 1) the "species dimension", the within-years and withinsite data contribute largely to the overall biomass, total densities, and structure of the community at the site in terms of relative abundances. Along 2) the "sites dimension", data contribute to a description of species turnover (or B-diversity) of birds over habitats, providing species-specific habitat utilization patterns. The "time dimension" 3) gives a picture of inter-year variation, qualified by species and by habitats.

A variety of statistical procedures can be employed to demonstrate the trends within the 3-D matrix. Some, such as MANOVA on species X sites $X$ years, will give a general indication of effects, while other multivariate techniques can address more specific questions. Habitats will be ordinated using some form of factor analysis (e.g. PCA or DECORANA) on vegetation structure, and the associations of species $\mathrm{X}$ habitats can be described and tested using either discriminant functions (DFA) or canonical correlation analysis (CCA). Longer time series data can be subjected (via TSA) to 
analysis for shorter- or longer-term cyclicity or fluctuations within species, and of course higherorder tests of a similar nature can be conducted by grouping species' densities into guilds of ecologically similar species, within which density compensation, or habitat use compensation, is most likely to occur. The computer facilities (hardware and software, data storage, and analytical capabilities) for these tasks are already in hand.

\section{WILLOWS: A HABITAT "OUTGROUP"}

While the logistic advantages of monitoring songbirds in a diverse range of habitats within one local area (GTNP) are obvious, questions about the local versus more regional nature of year-to-year density variations or longer-term trends will arise. Plans are afoot to census one habitat type, willow scrub, at several locations in the central to northern Rockies, from Colorado to Montana. Such "outgroup" censuses will provide an index of the extent to which GTNP trends match (or otherwise) those of the broader geographic region.

Willows sites will be matched as closely as possible by vegetation structure, and located preferentially in the major national parks of the region (Rocky Mountain through Yellowstone to Glacier). Census methodology at these sites will match that followed within GTNP, but the timing and rotation of the censuses may have to vary because of the more widespread nature of the outgroup sites.

\section{ADVANTAGES OF LONG-TERM MONITORING SCHEMES}

This work initiates a monitoring of the population trends of landbirds in relatively stable and pristine habitats that are protected at least from anthropogenic disturbances. Such habitat qualities offer several important advantages. First, monitoring can potentially continue indefinitely at the same sites every year, thereby ensuring strict comparability between and among years. Second, trend data will be free of influences by local, unnatural habitat changes or modifications, or by other intrinsic perturbations. Finally, the project will establish baseline data on the natural distribution over habitats and breeding densities (with means and variances) of most species of GYE landbirds. These data, in turn, could be used for comparisons with populations in similar but disturbed, manipulated, or fragmented habitats of similar vegetation types elsewhere, such as those commonly occurring on U.S. Forest Service and Bureau of Land Management holdings in the northern Rocky Mountains. This aspect of the proposed work is directly related to the Neotropical Migratory Bird Conservation Program's habitat management and conservation goals.

Besides the monitoring of bird populations, we will collect data on local variables that can affect bird populations either indirectly (e.g. from weather variables to water levels) or more directly (e.g. vegetation densities and insect productivities). Thus a wide range of critical questions relevant to population monitoring, community composition, and species diversity and density will be addressed in this research. The projected data analysis will reflect this wide range of questions, and present the results in a comparative fashion: among species, among sites (habitats), among years.

The project will establish formats for the strict comparison of bird density data among sites and between years. The proposed research is habitat- and site-based, rather than species-based; as all species in the local (site) communities are assessed, year-to-year adjustments in community structure will also be measurable (e.g. density compensation, when lower density in one species is associated with higher density in a second species). For example, a lower variation in total site bird density than in individual species' densities, among years, is evidence that density compensation occurs (see Tables 3, 4). Across sites, variations in overall bird densities, as well as the densities of individual species, will be evaluated. We note also that species that occur, for example, in lower density in one year in one habitat may or may not show a similar trend in other habitats in that year; species' densities among habitat types may be at least partially uncoupled.

Another aspect of interest is the extent to which a species' utilization of different habitats changes as its density changes from year to year. There is evidence from GTNP, for example, that some bird species are more precise in their habitat selection when their population densities are low, whereas a wider range of habitat types is utilized when densities are normal or high (Cody 1992). Our data will allow an evaluation of the trade-off between population density and use/availability of different habitats. 
Besides a within-community density compensation, as with increased density of a species at a site when a competitor is at low density, there may be habitat use compensation, exemplified when a species occurs in a given habitat only when a competitor is absent or at low density in that habitat. Possibly the invasion of the willows (site \#8) by Savannah sparrows in the absence of Clay-colored sparrows since the 1960's, or the increased use of the Grass-sage (site \#3) by Chipping sparrows in later years when congeneric Brewer's sparrows have been less common, are examples of this phenomenon.

\section{$\checkmark$ LiTERATURE CITED}

Bibby, C.J., N.D. Burgess \& D.A. Hill. 1992. Bird Census Techniques. Academic Press, London, New York, Orlando. pp. 257.

Cody, M.L. 1974. Competition and the Structure of Bird Communities. Monogr. Pop. Biol., Princeton Univ. Press, Princeton, NJ.

Cody, M.L. 1981. Habitat selection in birds: the roles of habitat structure, competitors, and productivity. Bioscience 31:107-113.

Cody, M.L. 1983. The land birds. Ch. 8, pp. 210245 In Island Biogeography in the Sea of Cortez (T.J. Case \& M.L. Cody, eds.). Univ. of California Press, Berkeley \& Los Angeles.

Cody, M.L. 1985. Habitat selection in birds. Academic Press, Orlando, FL.

Cody, M.L. 1991. Population densities and community structure of birds in Jackson Hole: a reassessment after 25 years. pp. 144-147 In UW/NPS Res. Cent. 15th Annual Report.

Cody, M.L. 1992. Population densities and community structure of birds in Jackson Hole; a reassessment after 25 years. pp. 330 In UW/NPS Res. Cent. 16th Annual Report.
Cody, M.L. 1993. Population densities and community structure of birds in Jackson Hole: A reassessment after twenty-five years. Bull. Ecol. Soc. 74 (Suppl.): 195.

Flack, D. 1976. Bird populations of aspen forests of western North America. Ornithological Monographs \#19. American Ornithologists Union.

Hutto, R.L. 1980. Winter habitat distribution of migrant landbirds in western Mexico, with specific reference to foliage-gleaning insectivores. In Keast, A., and M. Morton eds., Migrant landbirds in the neotropics: Ecology, behavior, distribution and conservation. Smithsonian Inst., Washington, D.C.

Hutto, R.L. 1986. Migratory and birds in western Mexico: a vanishing habitat. Western Wildlands 11:12-16.

James, J.C., and H.H. Shugart. 1970. A quantitative method of habitat description. Audubon Field Notes 24:727-736.

Keast, A., and M. Morton (eds.). 1980. Migrant landbirds in the neotropics: Ecology, Behavior, Distribution and Conservation. Smithsonian Inst., Washington, D.C.

Kendeigh, S.C. 1944. Measurement of bird populations. Ecol. Monogr. 14:67-106.

Knight, D.H. 1994. Mountains and Plains: The Ecology of Wyoming Landscapes Yale Univ. Press, New Haven, CT. pp. 372.

Love, J.D., and J.C. Reed, Jr. 1968. Creation of the Teton Landscape. Grand Teton Nat. Hist. Assoc., Moose, WY. pp. 120.

National Fish and Wildlife Foundation. 1992. Neotropical Migratory Bird Conservation Program. Washington, D.C. pp. 9.

Noon, B.R. 1980. Techniques for sampling avian habitats. pp. 42-52 In D.E. Capen (ed.), The Use of Multivariate Statistics in Studies of Wildlife Habitat. USDA Forest Service Gen. Tech. Rep. RM-87. 
Ralph, C.J., F.R. Geupel, P. Pyle, T.E. Martin, and D.F. DeSante. 1992. Field methods for monitoring landbirds. Draft MS. USDA Forest Service, Redwood Sciences Laboratory, Arcata, CA.

Salt, G.W. 1957. Song, Lincoln's and fox sparrows in a Tetons willow thicket. Auk 74:258.

Smithsonian Institution. 1991. Birds over Troubled Forests. Smithsonian Migratory Bird Center, National Zoological Park, Washington, D.C.
Terborgh, J. 1989. Where Have All the Birds Gone? Princeton Univ. Press, Princeton, NJ. pp. 207.

Wiens, J. 1984. Habitat selection in variable environments: shrub-steppe birds. Ch. 7 in Cody 1985, q.v.

Weins, J. 1988. Community Ecology of Birds. Cambridge Univ. Press, v. 1,2. 


\section{APPENDICES}

\section{APPENDIX A}

Existing and proposed census sites in GTNP; 24 sites are listed below, of which one ${ }^{* * *}$ has been studied by G. Salt since the 1950's and by M. Cody since the 1960 's, four ${ }^{* *}$ have been censused (by D. Flack and M. Cody) since the 1960's, and a further $11^{*}$ are already established (with census data by MLC since 1991). Additional sites will be established at project initiation, depending on available personnel.

\section{Site \# Location}

Habitat

Elev (m)

1. Wolf Ranch

Grazed meadow 2045

2. Jackson Lake Junction*

3. Jackson Lake Junction**

4. Jackson Hole Airport*

5. Two-ocean Lake Rd.*

6. Wet marsh

7. Snake River Bottoms*

8. Jackson Hole Junction***

9. Oxbow bend*

10. Elk Ranch West**

11. Elk Ranch East**

12. Signal Mountain**

13. Spread Creek*

14. Schwabacher Landing*

15. JY Ranch

16. Granite Canyon mouth

17. Timbered Island Moraine

18. AMK Ranch*

19. Signal Mountain*

20. Lizard Creek*

21. Jenny Lake*

22. Jackson Lake West

23. Upper Granite Canyon

24. Rendezvous Mountain

25. Moose

26. Lupine Meadows
Grass-sedge meadow 2053

Grass-sagebrush 2043

Tall sagebrush $\quad 1956$

Forb-meadow 2158

Moose-Wilson Rd. $\quad ? 1900$

Dry willow flats $\quad 2003$

Wet willow flats $\quad 2049$

Willow-aspen $\quad 2040$

Low aspen wdland $\quad 2109$

Mid aspen wdland $\quad 2152$

Tall aspen wdland 2091

Cottonwoods 2085

Cottonwoods 1988

Aspen-lodgepole wdland ?1964

Lodgepole-aspen wdland ?1945

Lodgepole-limber pine ?2090

Lodgepole pine forest 2055

Lodgepole-fir forest $\quad 2258$

Lodgepole-spruce-fir $\quad 2194$

Spruce-fir forest 2197

Spruce-fir forest ?2120

Subalpine fir forest $\quad ? 2500$

Arctic-alpine $\quad ? 3150$

Lodgepole pine burn $\quad ? 2100$
Sage-bitterbrush $\quad 1967$
APPENDIX B

Census rotation: 18 sites, 3 censuses/day, 3-woek rotation

\begin{tabular}{|c|c|c|c|c|c|c|c|c|}
\hline \multirow{2}{*}{$\begin{array}{l}\text { Week } 1 \\
\text { Time: 6-8a }\end{array}$} & \multirow[b]{2}{*}{$8-10 a$} & \multirow{2}{*}{\multicolumn{2}{|c|}{ Woek 2}} & \multicolumn{5}{|c|}{ Woek 3} \\
\hline & & & & $6-8 a$ & $8-10 a$ & $3-5 p$ & 68 & $8-10 a$ \\
\hline Day 1: 1 & 2 & 3 & & 18 & 1 & 2 & 17 & 18 \\
\hline Day 2: 4 & 5 & 6 & & 3 & 4 & 5 & 2 & 3 \\
\hline Day 3: 7 & 8 & 9 & & 6 & 7 & 8 & 5 & 6 \\
\hline Day 4: 10 & 11 & 12 & & 9 & 10 & 11 & 8 & 9 \\
\hline Day 5: 13 & 14 & 15 & & 12 & 13 & 14 & 11 & 12 \\
\hline Day 6: 16 & 17 & 18 & & 15 & 16 & 17 & 14 & 15 \\
\hline
\end{tabular}

